\title{
Non-European shipwrecks of the western Indian Ocean
}

\author{
Caesar Bita* \\ National Museums of Kenya, Department of Coastal Archaeology, Fort Jesus World Heritage Site, P.O. Box 82412-80100, Mombasa, Kenya
}

\begin{abstract}
The western Indian Ocean (WIO) along the East African coast, popularly known as the Swahili coast, stretches between lat $15^{\circ} 48^{\prime} 0^{\prime \prime} \mathrm{N}$ and $14^{\circ} 53^{\prime} 5^{\prime \prime} \mathrm{N}$ and long $74^{\circ} 20^{\prime} 1^{\prime \prime} \mathrm{E}$ and $7^{\circ} \mathbf{4 0}^{\prime} 3^{\prime \prime} \mathrm{E}$. The Swahili coast extends $3000 \mathrm{~km}$ from Somalia to the north through Kenya and Tanzania to Mozambique in the south. It also includes island states of Comoro, Seychelles, Madagascar, Reunion and Mauritius. The characteristics of the coastal areas of continental countries and Madagascar are similar: alternating beaches, rocky outcrops, coral reefs, large estuarine areas, wetlands, lagoons and inter-tidal fiats. The coastline consists of reefs, lagoons, beaches, rivers, creeks and low-lying coastal plains. For hundreds of years, by using different types of water crafts, maritime traders have sailed the Indian Ocean, governed by adequate knowledge of regular and predictable monsoon winds blowing between the Indian subcontinent and Africa. The east African coast occupies a significant place in the maritime activity and trade contacts with the external world in the Indian Ocean.
\end{abstract}

Keywords: Anchor, copper ingots, Mombasa, Mtepe, Swahili.

\section{Introduction}

ANCIENT records reveal the prevalence of thriving maritime activity along the east African coast ${ }^{1-5}$. The Swahili coast was an important player in the transoceanic western Indian Ocean (WIO) maritime trade. For instance, records allude to vibrant mangrove export trade from Ngomeni, Malindi, Kenya to the Middle and Far East during the 13 th century CE. Historical coastal settlements of Kismayo, Lamu, Zanzibar, Kilwa and Sofala were important port towns, as they were strategically situated along busy sea lanes. During the early centuries CE trade took place at inland ports which were connected by river routes. Since seagoing ships could not sail up the narrow rivers, traditional boats such as sewn and nailed plank boats or extended logboats might have been in use for inland transportation. The author of the Periplus Maris Erythraei mentions the role of traditional boats in hinterland and maritime trade $\mathrm{e}^{6,7}$.

\footnotetext{
*e-mail: mcbita@museums.or.ke
}

\section{Traditional ships in the Swahili coast}

Various types of traditional boats have existed along the Swahili coast, including sewn plank boats popularly known as the Mtepe, logboats and plank boats. GrecoRoman visitors mention African sewn boats as early as 4th century $\mathrm{CE}$ (refs 6, 8-10). Archaeological evidence for early boats in the Swahili coast is, however, not consistent. There are boat models depicted on the walls of ancient settlements. Surveys and excavations at ancient towns of Kilepwe along Mida creek off the ancient city of Gede and Mtwapa in Kenya, Kilwa and Ras Mkumbu in Tanzania have yielded boat illustrations and graffi$\mathrm{ti}^{3,5,11,12}$. These boat graffiti probably depict the mtepe type of boat that plied the Indian Ocean in the last centuries before CE. Further, these are the boats referred to by the Portuguese and are believed to have been in use in the Swahili coast until the early centuries of the Common Era. They also depict the maritime trade in the WIO before the arrival of the Portuguese and complement documentary sources of vessels used along this coast as mentioned in the Periplus ${ }^{6,7,12,13}$.

\section{Non-European shipwrecks of western Indian Ocean}

There has not been a systematic underwater survey off the Swahili coast, including its islands, for shipwrecks. Although the coast is dotted with historic period settlements, however, the archaeological investigations have not produced the much desired information on the coastal communities. The dangers of shipping in the ancient times are known and many western shipwrecks are reported lost in these waters ${ }^{14,15}$. There has not been serious maritime study of this coast. Patience ${ }^{15}$, who did many commercial salvage operations on the Swahili coast has documented over 100 shipwrecks, all of them of European origin.

Some of the underwater surveys undertaken off the Swahili coast have brought to light a few shipwreck sites. In Lamu, surveys have recovered anchors, wooden features and Chinese porcelain on the seabed along the Pate Bay (Figures 1 and 2) including a pot with dragon emblems, typical of Chinese motifs of the 14th century CE (refs 16-18). Dragon motifs are the emblems of the 
Chinese Ming Dynasty emperors. During the Ming dynasty, the Chinese are known to have launched maritime missions to African countries ${ }^{3,19}$. During one of these voyages to East Africa one of the Chinese junks sank near Pate Island.

Maritime surveys in Malindi have documented several sites that are yet to be confirmed as shipwrecks. These include a 14th-15th century CE wooden shipwreck containing Chinese and Indian pottery off Leopard Bay reef $^{15,18}$. An object rising about 100 feet $(30.48 \mathrm{~m})$ from the sea floor has been called 'Mambrui lump'. This

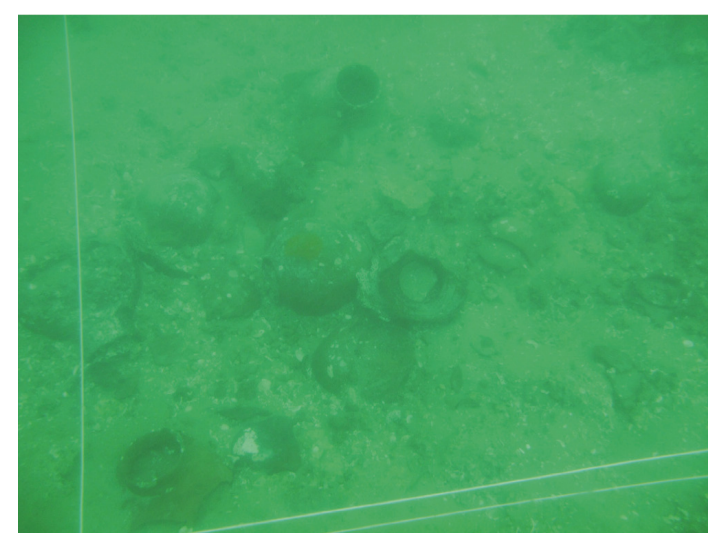

Figure 1. Shipwreck sites in Lamu with anchor and pottery scatter ${ }^{18}$.

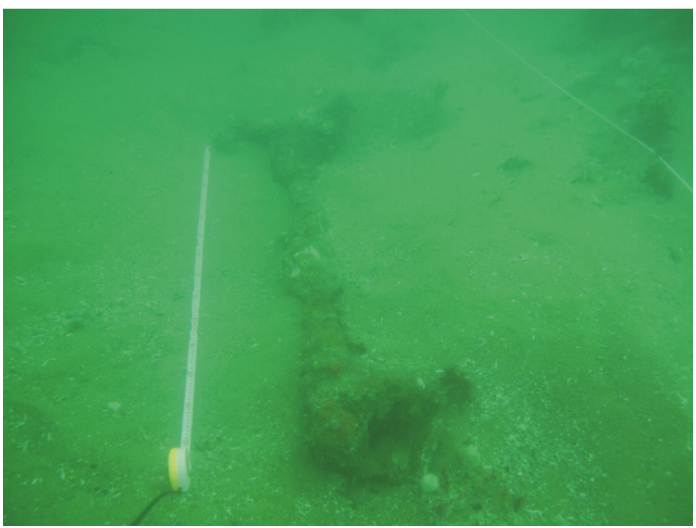

Figure 2. Shipwreck sites in Kenya with anchor and pottery scatter ${ }^{18}$.

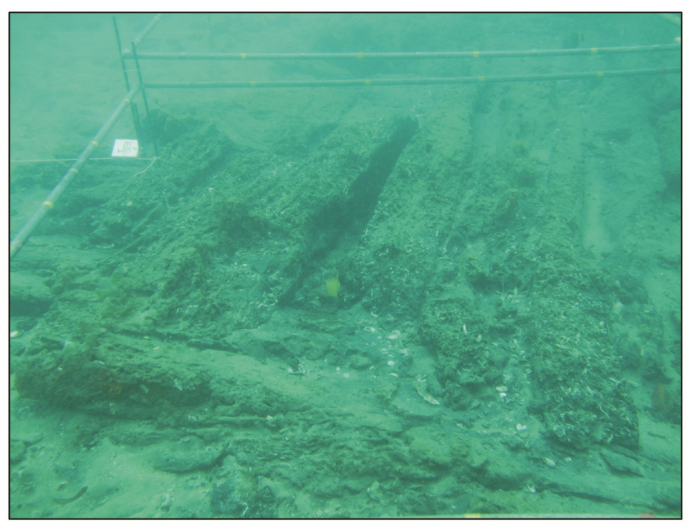

Figure 3. The Ngomeni shipwreck site ${ }^{21}$. feature has been sighted by several sailors who have noticed unusual structures in the seabed of Ungwana Bay $^{20}$. Further, a 15 th century CE shipwreck in Ngomeni, $30 \mathrm{~km}$ north of Malindi town has produced huge amounts of Islamic and Far Eastern wares dating to 13-15th century CE (ref. 21). However, presence of copper ingots with a visible trident seal similar to the Fugger family crest has raised doubts as to whether this was an Arabic or Portuguese vessel (Figure 3). The Fugger was a prominent merchant and banking family from Germany. Together with others such as the Welser family, the Fuggers are known to have supplied merchandise that formed part of the commercial artery of the Portuguese crown ${ }^{22}$.

Maritime surveys in Mombasa have documented an array of shipwreck sites (Figure 4). A collaborative geophysical survey of Mombasa Island revealed numerous underwater sites, some of which may be shipwrecks ${ }^{23-26}$. Further, underwater surveys in 2008 at the channel

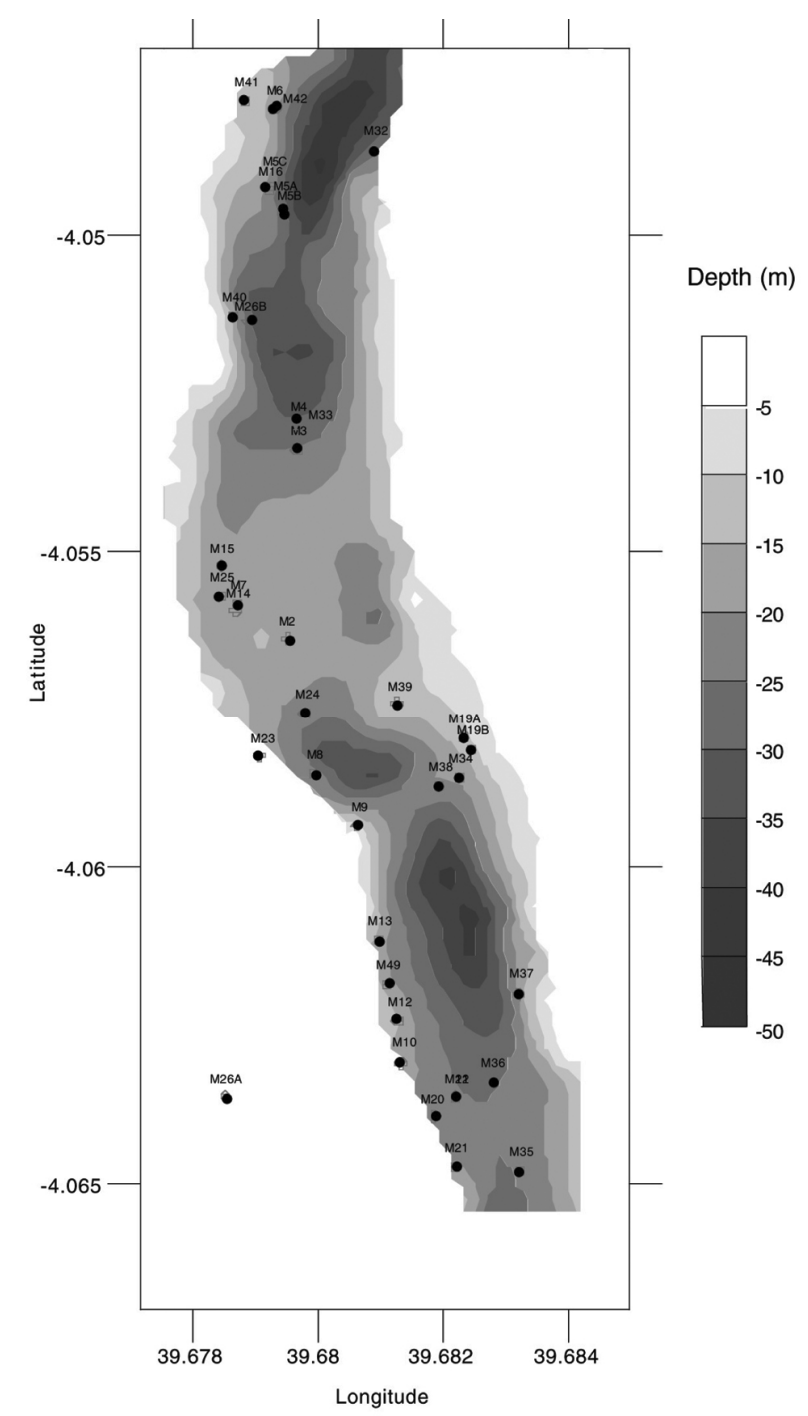

Figure 4. Underwater sites around Mombasa Island and a shipwreck embedded in concretion found near the site where stone anchors were found 26,35 .

CURRENT SCIENCE, VOL. 117, NO. 10, 25 NOVEMBER 2019 


\section{SPECIAL SECTION: SHIPWRECKS}

entrance to the ancient port of Mombasa recovered three stone anchors ${ }^{27}$. Among these, one is an Indo-Arabian type while the other two are composite types ${ }^{28}$. The shape and size of the three stone anchors resembles anchors found along the Indian, Sri Lankan and Oman coasts and the Mediterranean region ${ }^{29-35}$. The presence of these stone anchors suggests possible ancient non-western shipwrecks in the waters of Mombasa.

\section{Conclusion}

Evidence that depicts earlier non-western vessels such as ships, dhows and canoes are known from various ancient Swahili settlements along the east African coast. These range widely in data from charcoal drawings of the 15 th century CE, Mtepe found in Fort Jesus, to the 15-16th centuries CE Swahili coastal towns of Kilwa, Ras Mkumbu in Tanzania; Mida and Kilepwe in Kenya. These engravings provide best evidence until such a time as actual shipwrecks are discovered.

1. Datoo, B. A., Rhapta: the location and importance of East Africa's first port. Azania, 1970, 5, 65-77.

2. Hall, R., Empires of the Monsoon, A History of the Indian Ocean and its Invaders, Harper Collins, London, 1996, pp. 33-142.

3. Kirkman, J., Men and Monuments on the East African Coast, Lutterworth Press, London, 1964.

4. Martin, E. B. and Martin C. P., Cargoes of the East: The Ports, Trade and Culture of Arabian Seas and Western Indian Ocean, Tree Books, Elm, 1978.

5. Kusimba, C. M., The Rise and Fall of Swahili States, Altmara Press, London, 1999.

6. Casson, L., The Periplus Maris Erythraei, Princeton University Press, New Jersey, 1989.

7. Horton, M. C., The Periplus and East Africa. Azania, 1990, 25 , 95-99.

8. Chami, F., The Unity of African Ancient History: 3000 BC to 500 $A D$, E and D Vision Publishers, Dar es Salaam, 2006, pp. 3-219.

9. Freeman-Grenville, G. P., The East African Coast: Selected Documents from the First to Earliest Nineteenth Century, Clarendon Press, Oxford, 1975, vol. 3

10. Freeman-Grenville, G. P., The Medieval History of the Coast of Tanganyika, Oxford University Press, London, 1962, pp. 106-111.

11. Kirkman, J., The excavations at Kilepwe. Antiquaries J., 1952, 32 $168-184$.

12. Gilbert, E., The Mtepe: regional trade and the late survival of sewn ships in East African waters. Int. J. Naut. Archaeol., 1998, 27, 43-50.

13. D'Souza, B. R., Harnessing the Trade Winds, Zand Graphics, Nairobi, 2008, pp. 13-183.

14. Guinote, P., Frutuoso, E. and e Lopes, A., Naufrágios e outras perdas de Carreira da Índia, Lisboa: Grupo de Trabalho Ed do Ministério da Educação para as Comemorações dos Descobrimentos, 1998.

15. Patience, K., Shipwrecks and Salvage on the East African Coast, Dar Akhbar Al Khaleej, Bahrain, 2006, pp. 11-276.

16. Bita, C. and Wanyama, P., Preliminary Intertidal and Underwater Archaeological Survey of Lamu Archipelago, Research Report, Fort Jesus Museum, Mombasa, 2007.

17. Bita, C., The potential of underwater archaeology in Kenya: a short communication. In Shipwrecks Around the World: Revela- tions of the Past (ed. Sila Tripati), Delta Book House, New Delhi, 2015, pp. 486-510.

18. Bita, C., Ancient Afro-Asia links. evidence from a maritime perspective. J. Indian Ocean Archaeol., 2013, 9, 1-10.

19. Inghams, K., A History of East Africa, Longman, London, 1962, 5.

20. Bita, C., The Western Indian Ocean Maritime Heritage: An overview of the maritime archaeological heritage in Malindi, British Institute in Eastern Africa, Nairobi, 2008.

21. Bita, C., Ngomeni Shipwreck: its discovery and what it tells us about the 16th century transoceanic trade. Kenya Past Present, 2018, 45, 33-44.

22. Chalmin, P., Trade and Merchants: Panorama of International Commodity Trading, Harwood Academic Publisher, London, 1987.

23. Forsythe, W., Quinn, R. and Breen, C., Subtidal archaeological investigations in Mombasa's Old Port. In Researching Africa's past: New Contributions from British Archaeologists (eds Mitchell, P., Haour, A. and Hobart, J.), Oxford University School of Archaeology Monograph 57, Oxbow Books, Oxford, 2003, pp. 133-138.

24. Rory, Q., Wes, F., Colin, B., Donal, B., Paul, L. and Athman, L., Process-based models for Port evolution and wreck site formation at Mombasa. Kenya. J. Archaeol. Sci., 2007, 34, 1449-1460.

25. McConkey, M. and McErlean, T., Mombasa Island: a maritime perspective. Int. J. Hist. Archaeol., 2007, 11(2), 99-121.

26. Bita, C. and Wanyama, P., Underwater Archaeological Impact Assessment for the LION 2 (Telkom/Orange) Undersea Fibre Optic Cable, Mombasa, Kenya, 2011.

27. Bita, C. and Sila Tripati, Stone anchors from Mombasa, Kenya: evidence of maritime contacts with Indian Ocean countries. Bull. Australasian Inst. Maritime Archaeol., 2015, 39, 84-91.

28. Gaur, A. S., Sundaresh. and Vora, K. H., Underwater Archaeology of Dwarka and Somnath, Aryan Books International, New Delhi, 2008, pp. 24-57.

29. Tripati, S., Gaur, A. S. and Sundaresh, Anchors from Goa waters, Central West Coast of India: remains of Goa's overseas trade contacts with Arabian countries and Portugal. Bull. Australasian Inst. Maritime Archaeol., 2003, 27, 97-106.

30. Tripati, S., Gaur, A. S., Sundaresh and Bandodker, S. N., Historical period stone anchors from Vijaydurg on the west coast of India. Bull. Australasian Inst. Maritime Archaeol., 1988, 22, 1-8.

31. Sila Tripati, Stone anchors of India: findings, classification and significance. In Proceedings of the 2nd Asia-Pacific Regional Conference on Underwater Cultural Heritage (eds Tilburg, Hans Van., Sila Tripati, Walker, V., Fahy, B. and Kimura, J.), Honolulu, Hawaii, 2014, 2, 973-986.

32. Souter, C., Stone anchors near Black Fort, Galle, Sri Lanka. Int. J. Naut. Archaeol., 1988, 27, 331-342.

33. Vosmer, T., Indo-Arabian stone anchors in the western Indian Ocean and Arabian Sea. Arabian Archaeol. Epigraphy., 1999, 10, 248-263.

34. Le Pard, G., The study of stone anchors in Dorset, UK. In Maritime Contacts of the Past Deciphering Connections Amongst Communities (ed. Sila Tripati), Delta Book House, New Delhi, 2015, pp. 590-602.

35. Breen, C. and Lane, P., Archaeological approaches to East Africa's changing seascapes. World Archaeol., 2003, 35, 469-89.

ACKNOWLEDGEMENTS. I thank the British Institute in Eastern Africa for continued support of research in the western Indian Ocean region. I thank UNESCO, Italian Embassy, Nottingham University, The International Academy of Underwater Sciences and Techniques, the Kenyan Government and National Museums of Kenya for supporting $\mathrm{UCH}$ programmes in Kenya.

doi: $10.18520 / \mathrm{cs} / \mathrm{v} 117 / \mathrm{i} 10 / 1687-1689$ 